Brit. F. vener. Dis. (1967), 43, 150.

\title{
GONOCOCCAL BARTHOLINITIS*
}

\author{
BY
}

\author{
ELISABETH REES \\ Liverpool Royal Infirmary
}

The greater vestibular or Bartholin's glands have long been recognized as possible foci of gonococcal infection in the female. In 1737, Astruc, royal professor of medicine and physician to Louis XV of France, referred to the "Humours to be peculiarly distinguished that may be infected with the venereal poison and bring on local diseases upon those parts". One of the "humours" he distinguished was "The unprolific semen in either sex, of the prostates, Cowper's glands, and of the lacunae of the urethra in men; but in women of the prostates, Cowper's glands, and the glands of the vagina".

* Received for publication February 9, 1967.
References to the incidence of gonococcal bartholinitis are rare. Nicol (1948) found five cases in 229 patients with gonorrhoea. Dunlop (1963) reported that bartholinitis produced the presenting symptom in three out of seventy cases of symptomatic gonorrhoea in women. Shapiro and Lentz (1965), in a comprehensive paper on gonorrhoea in females, although including Bartholin's glands in the list of "time-honoured sites of involvement", did not mention the glands in the description of their technique of investigation. They say evaluation of the urethra, vagina, cervix, and endocervix must be made. Most writers refer to bartholinitis in general terms as a local complication resulting in pain and swelling or abscess formation.

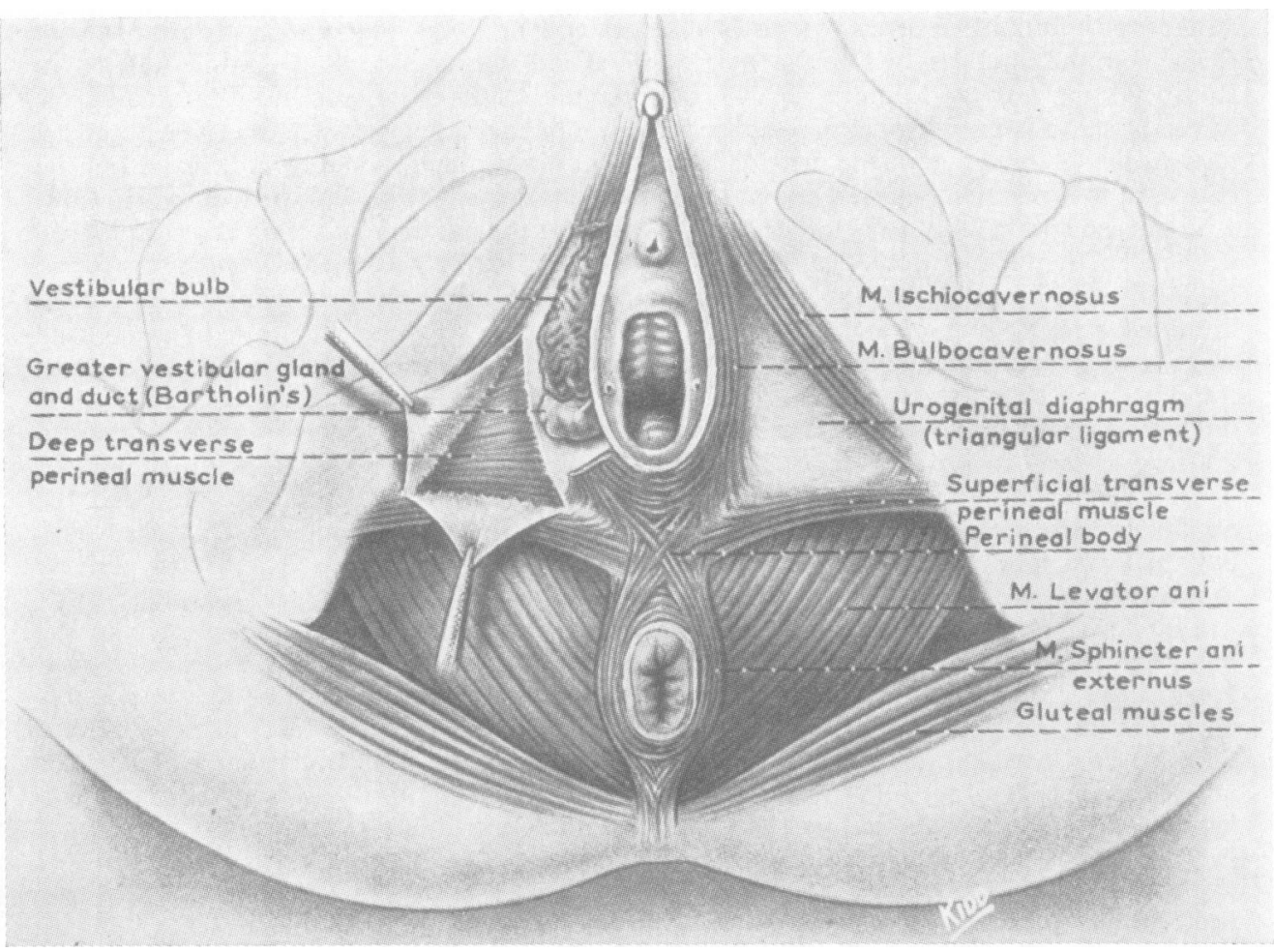

FIG. 1.-The urogenital diaphragm (triangular ligament) and associated structures as seen from below. 
Durel (1950), however, recognized a "bartholinite canaliculaire" in which the infection limited itself to the ducts of the glands, there being no swelling. The orifice was usually inflamed and yielded a purulent discharge. He said that the physiological mucous secretion produced in quantity at coitus might be present constantly but had little pathological significance.

The general pattern of gonococcal infection in the female would suggest that, as in all other sites, urethra and para-urethral ducts, cervix, and rectum, in a high proportion of cases of bartholinitis clinical signs will be minimal or indeed absent. This, together with the fact that the anatomy and histology of the ducts makes them particularly vulnerable to attack by the gonococcus, suggests that bartholinitis may commonly occur and remain undiagnosed.
Anatomy and Histology

Bartholin's glands are the homologue of Cowper's glands in the male. They lie, one on either side of the lower part of the vagina, below the perineal membrane and are covered by the posterior parts of the bulbs of the vestibule. Each is about $1 \mathrm{~cm}$. in diameter and its slender duct, $2 \mathrm{~cm}$. in length, opens into the vestibule adjacent to the hymen at the junction of the middle and posterior third of the labium minus (Fig. 1).

They are compound tubulo-alveolar mucous glands (Fig. 2), the smaller ducts being lined by simple columnar epithelium and the larger ones by stratified columnar epithelium. The latter is rare and covers small wet surfaces in the body that need more protection than that afforded by simple columnar epithelium. It is found in the fornix of the conjunctiva, the cavernous part of the urethra, parts
FIG. 2.- Section of gland of Bartholin. A large duct with patches of stratified columnar epithelium $(c)$ gives off smaller branches lined with columnar mucous cells $(b)$ and continuing into tubulo-alveolar terminal portions which are lined with large mucous cells $(a)$ $d$, interstitial connective tissue; $v$, blood vessel.

$\times$ 185. (A.A.M.)

(Reproduced from Bloom and Fawcett (1962), p. 616, figs 30-34, by permission of the publishers.)

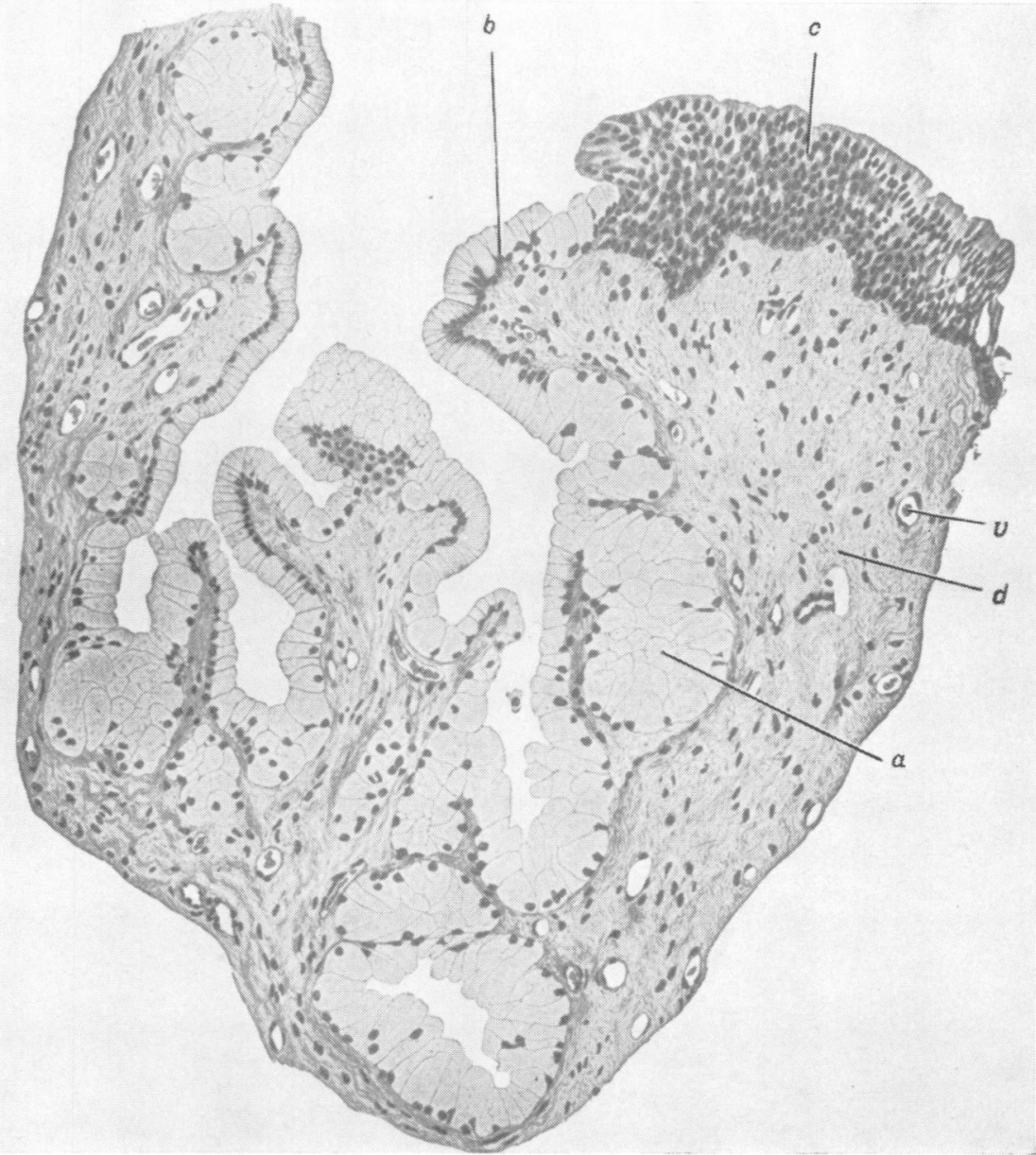


of the anal mucous membrane, the pharynx, the epiglottis, and the large excreting ducts (Bloom and Fawcett, 1962). The deeper layers consist of small polyhedral cells and the surface layer of tall columnar cells. Some gynaecological pathologists (Novak and Novak, 1958) state that Bartholin's ducts are lined by transitional epithelium which would resist penetration by gonococci. Histologists (Ham and Leeson, 1961 ; Bloom and Fawcett, 1962) say that transitional epithelium is adapted to lining tubes and the walls of hollow organs which are subject to great mechanical changes due to contraction and distension, notably the bladder. The deeper layers consist of columnar or cuboidal cells, followed by layers of polyhedral cells, while the superficial layer consists of large flattened cells with a convex free surface (Fig. 3). In chronic inflammatory conditions one type of epithelium may change into another by the process of metaplasia (Bloom and Fawcett, 1962). Thus columnar epithelium of the bronchi may change to stratified squamous epithelium. It would appear possible that metaplasia of the lining epithelium of Bartholin's cysts, due to pressure of the cyst contents, could result in the change from the stratified columnar epithelium of the larger ducts to the transitional epithelium of Bartholin's cyst walls reported by Novak and Novak (1958) and illustrated recently by Hutfield (1965). The difference between the pathologists and the histologists is that the former are dealing with abnormal tissue, which has been subjected to an inflammatory process and, in the case of cysts, to pressure.

\section{Pathology}

Harkness (1948) stated that gonococcal infection was usually confined to the ducts and periglandular

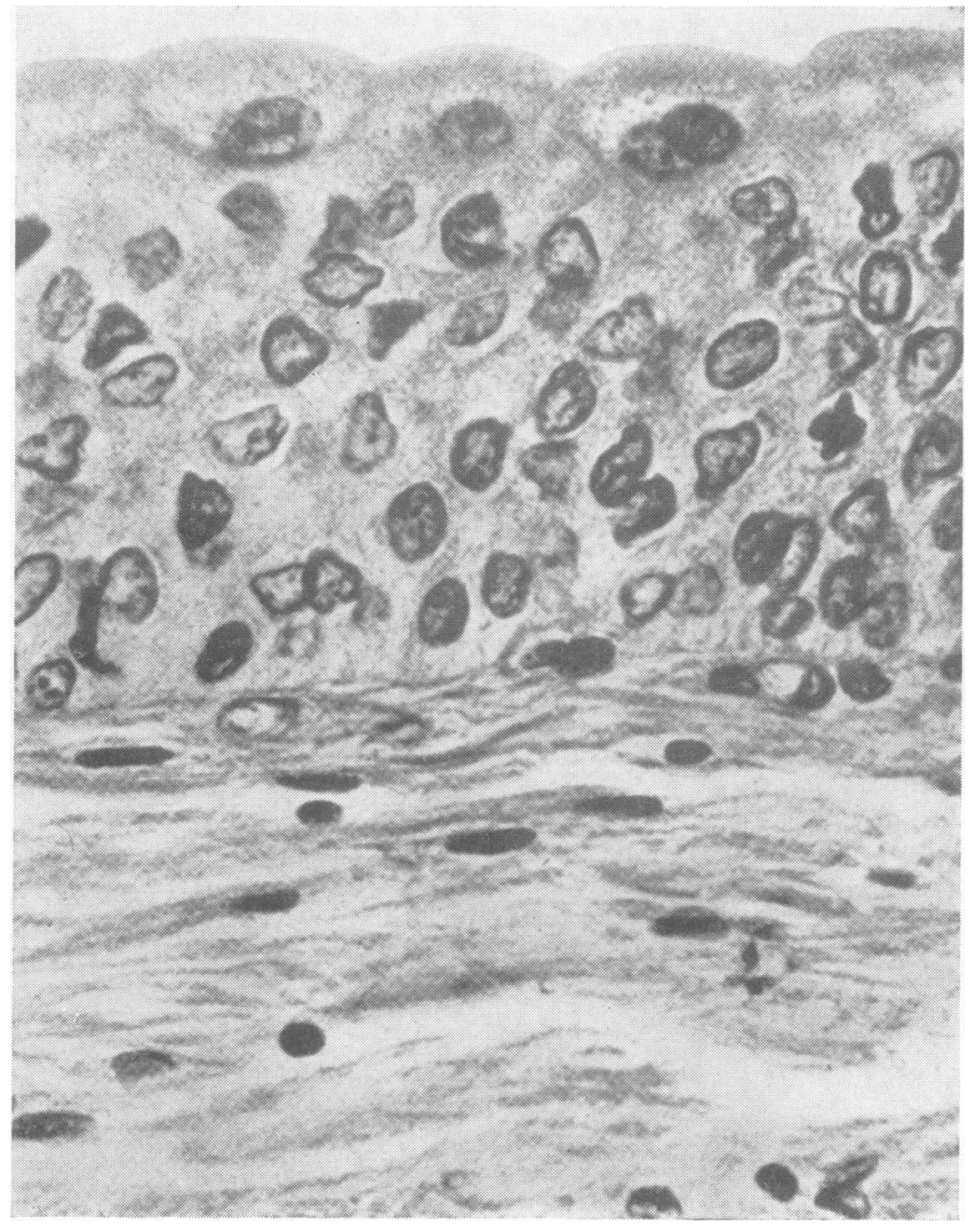

FIG. 3.-Medium-power photomicrograph of a section cut from the bladder of a dog. Transitional epithelium, when contracted, is characterized by the innermost cells; these show rounded, free borders which give the surface a scalloped appearance.

(Reproduced from Ham and Leeson (1961), p. 226, fig. 131, by permission of the publishers.) 
tissue and quoted Bumm (1884) and Jadassohn (1890) in support of the belief that the secreting function of the glands afforded immunity. The glands are not normally palpable through the vestibular body, but periglandular inflammation or blockage of a duct with pus may lead to any degree of swelling from barely palpable enlargement to a large abscess 2 " in diameter. It is suggested that it is this type of Bartholinitis which is relatively uncommon and is a complication of a gonococcal infection.

\section{Investigation}

This consists of inspection of the vulva, palpation of the glands, massage of the ducts, and microscopic examination and culture of any material obtained.

The results of such an investigation in 183 consecutive cases of gonorrhoea in women examined by the same clinician at the Liverpool Royal Infirmary between January 1, 1965, and March 31, 1966, are presented below.

\section{Results}

Gonococci were reported present in the secretion expressed from Bartholin's ducts in $52(28.4$ per cent.) of the 183 cases.

The character of the secretion varied from clear mucus to mucopus and the amount from a bead, sufficient only for a single swab for culture, to a small flow.

Table I shows the associated clinical signs in the 52 cases. The insignificance of these signs is demonstrated by the fact that in only one case was the presenting complaint referrable to the findings in Bartholin's glands (Table II).

TABLE I

CLINICAL SIGNS $\underset{\text { BARTHOLINITIS }}{\text { 52 CASES OF GONOCOCCAL }}$

\begin{tabular}{l|c}
\hline \multicolumn{1}{c|}{ Clinical Signs } & Number of Cases \\
\cline { 2 - 2 } Oedema of labium major & 2 \\
Enlargement of the gland with tenderness & 9 \\
Enlargement of the gland without tenderness & 1 \\
Tenderness of the gland with no enlargement & 1 \\
\hline
\end{tabular}

TABLE II

PRESENTING COMPLAINT IN ELEVEN CASES WITH PALPABLE ENLARGEMENT AND/OR TENDERNESS

\begin{tabular}{l|c}
\hline \multicolumn{1}{c|}{ Presenting Complaint } & Number of Cases \\
\hline Pain below & 1 \\
Pain or discomfort in stomach & 2 (salpingitis) \\
Discharge & 4 \\
No complaints & 4
\end{tabular}

The secretion was classified according to its appearance, types (1) and (2) being the normal secretion of the gland:

(1) Clear mucus

(2) Cloudy mucus-basically mucus with faint streaks of white or an overall faint cloudiness

(3) Mucoid-ranging from thin milky to thick white

(4) Mucopus - any degree of yellow from pale cream to yellowish-green

The correlation between the type of secretion expressed and the bacteriological results is shown in Fig. 4.
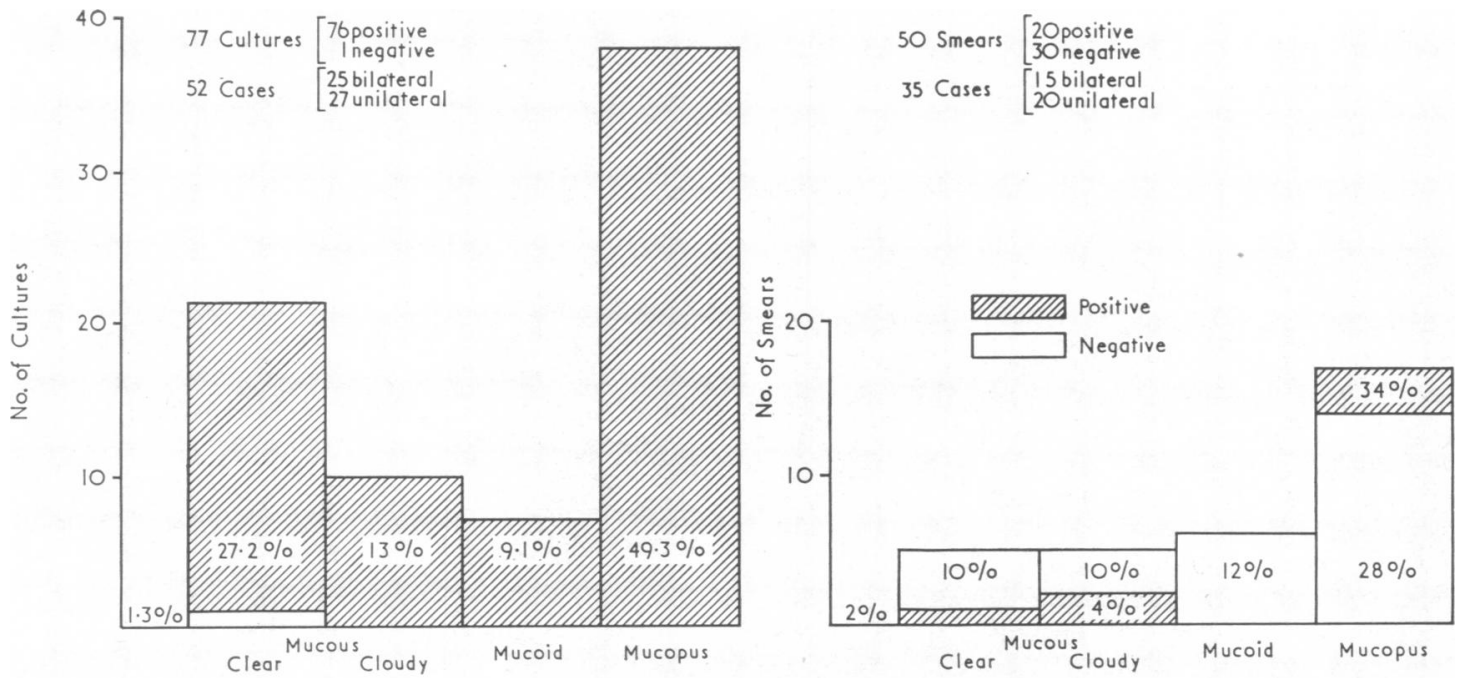

FIG. 4.-Correlation of bacteriological results with type of secretion. 
Culture plates were always inoculated with the first bead of discharge obtained. Re-massage of the duct was then carried out as in the taking of urethral specimens, but a further bead for smear examination was obtained in only 35 of the 52 cases.

The sensitivity to penicillin of all the strains isolated was tested (Table III); the overall incidence of strains showing decreased sensitivity to penicillin (minimum inhibitory concentration $0 \cdot 125-0 \cdot 5$ $\mathrm{u} / \mathrm{ml}$.) in the 205 female cases of gonorrhoea presenting at Liverpool Royal Infirmary during this 15month period was 35.9 per cent.

TABLE III

SENSITIVITY TO PENICILLIN OF STRAINS ISOLATED FROM 52 CASES OF GONOCOCCAL BARTHOLINITIS

\begin{tabular}{l|c|c|c|c|c|c|c}
\hline $\begin{array}{l}\text { Minimum } \\
\text { Inhibitory } \\
\text { Concentration } \\
\text { (units/ml.) }\end{array}$ & 0.5 & 0.25 & 0.125 & 0.06 & 0.03 & 0.015 & Subculture \\
\hline $\begin{array}{l}\text { Number of } \\
\text { Strains }\end{array}$ & $\begin{array}{l}1 \\
\begin{array}{l}24(47 \%) \\
\text { Lost on }\end{array}\end{array}$ & 8 & 12 & 6 & 9 & 1 \\
\hline
\end{tabular}

Complications were present in eleven cases (Table IV).

TABLE IV

ASSOCIATED COMPLICATIONS AND SENSITIVITY TO PENICILLIN OF STRAINS ISOLATED

\begin{tabular}{l|c|c|c|c|c|c|c}
\hline Complication & $\begin{array}{c}\text { Number } \\
\text { of } \\
\text { Cases }\end{array}$ & \multicolumn{5}{|c|}{$\begin{array}{c}\text { Sensitivity to Penicillin } \\
\text { (M.I.C. units/ml.) }\end{array}$} \\
\hline $\begin{array}{l}\text { Salpingitis } \\
\begin{array}{c}\text { Symptomatic } \\
\text { Proctitis }\end{array}\end{array}$ & 9 & 2 & $0 \cdot 25$ & $0 \cdot 125$ & $0 \cdot 06$ & $0 \cdot 03$ & 0.015 \\
\hline
\end{tabular}

\section{Treatment}

The standard treatment during this period was a single injection of fortified procaine penicillin 800,000 i.u. (procaine penicillin B.P. 600,000 i.u. (600 mg.) + benzylpenicillin B.P. 200,000 i.u. (120 mg.) ). It was thought that, in the absence of complications and in cases in which the bartholinitis was limited to the duct, standard treatment should be adequate provided that the strain isolated did not show decreased sensitivity to penicillin. Cases in which alternative treatment was given are listed in Table $\mathrm{V}$.

Tetracycline $500 \mathrm{mg}$. 6-hrly for 4 days was given to patients presenting enlargement and tenderness of the gland. In one case, in which these signs were minimal, standard treatment was given and resolution and cure followed.
TABLE V CASES IN WHICH ALTERNATIVE OR ADDITIONAL

\begin{tabular}{|c|c|}
\hline Reason for Alternative or Additional Treatment & $\begin{array}{l}\text { Number } \\
\text { of Cases }\end{array}$ \\
\hline $\begin{array}{l}\text { Salpingitis } \\
\text { Enlargement and tenderness of gland } \\
\text { (2 included under salpingitis) } \\
\text { (1 received standard treatment) } \\
\text { Concurrent primary syphilis } \\
\text { Admitted with acute vulvitis } \\
\text { Balance of cases with strains of gonococci relatively } \\
\text { insensitive to penicillin }(M \text {.I.C. } 0 \cdot 125-0.5 \mathrm{u} / \mathrm{ml} \text {.) } \\
\text { Socially vulnerable with borderline sensitive strains of } \\
\text { gonococci (M.I.C. } 0.6 \mathrm{u} / \mathrm{ml} \text {.) }\end{array}$ & $\begin{array}{r}1 \\
1 \\
12 \\
5\end{array}$ \\
\hline Total & 34 \\
\hline
\end{tabular}

Alternative treatment was usually given to patients whose smears were negative, but whose culture report, available at the time of re-attendance, showed a relatively insensitive strain of gonococcus. Additional treatment was usually given under the same circumstances if positive smears obtained at the first attendance had been treated by the standard routine. The alternative or additional treatment was usually ampicillin $1.0 \mathrm{~g}$.

One case defaulted before treatment.

The results in cases receiving standard treatment (Table VI) suggest that standard treatment for uncomplicated bartholinitis is adequate even in cases in which mucopurulent discharge is expressed.

TABLE VI

RESULTS IN CASES RECEIVING STANDARD TREATMENT

\begin{tabular}{|c|c|}
\hline Total No. of Cases & 17 \\
\hline No. Transferred immediately after treatment & 2 \\
\hline No. Available for Follow-up & 15 \\
\hline $\begin{array}{l}\text { Inadequate follow-up } \\
\text { (1 negative test-1 case) } \\
(2 \text { negative tests-1 case) }\end{array}$ & 2 \\
\hline $\begin{array}{l}\text { Follow-up tests }(3-7) \text { consistently negative or marital } \\
\text { intercourse resumed } \\
\text { Gonococci reported in culture in third follow-up tests } \\
(\text { M.I.C. } 0.6 \mathrm{u} / \mathrm{ml} \text {.) }\end{array}$ & $\begin{array}{r}12 \\
1\end{array}$ \\
\hline
\end{tabular}

Clinical assessment of the response to treatment was possible in cases in which mucopus or mucoid discharge was expressed. Usually such discharge had changed to cloudy or clear mucus when the patient was seen in 3-4 days, or from mucopus to mucoid in those in which a relatively large amount of mucopus had been expressed. The gland remained palpable in two cases after treatment. In one there was a small cyst-like swelling and in the other a non-tender induration rendering it just distinguishable from the vestibular body.

\section{Cases of Special Interest}

In two cases, one of primary infection and one of relapse, the diagnosis was made solely on 
demonstrating gonococci in culture of Bartholin's secretion. In both cases the urethral and cervical smears and cultures were negative.

In four cases, three of primary infection and one of relapse, gonococci were demonstrated in smears of Bartholin's secretion when urethral and cervical smears were negative. In these four cases cultures from all sites subsequently proved positive, but the finding of gonococci in the Bartholin's smears resulted in treatment being given without delay.

\section{Gonococcal Bartholinitis in the Absence of Visible Secretion}

The fact that gonococci were demonstrated in the normal clear mucous secretion of Bartholin's ducts suggested that they would also be present in the ducts in the absence of any visible secretion. To test this hypothesis, a lacrimal probe was introduced for a short distance into one or both ducts in a random selection of 28 such cases of gonorrhoea. These cases form a separate group from the series presented, there being no secretion expressed from the ducts. Anel's and Liebreich's lacrimal probes were both used, but the former was soon discarded as it was sharper and caused some discomfort to the patients. This did not occur when Liebreich No. 1 and 2 probes were used. Culture plates were inoculated by the probe.

Cultures were reported positive in fifteen $(53.6$ per cent.) of the 28 cases.

\section{Discussion}

The secretion obtained on massage of the ducts can be classified as visibly pathological (mucoid or mucopus) in 45 of the 77 specimens ( 58.4 per cent.), 36 of the 52 cases $(69 \cdot 2$ per cent.). It is usually stated that approximately 50 per cent. of female cases of gonorrhoea are asymptomatic and that clinical signs are absent. The rather higher figure obtained could be explained by the fact that in the absence of any secretion a routine specimen from the ducts was not obtained as it is in all other sites and the figures, therefore, are not comparable. If gonococci can be present in the ducts when secretion is not expressed, a true figure for the incidence of bartholinitis has not been obtained.

On the other hand the possibility cannot be excluded that gonococci reported present in the specimens of clear and cloudy mucus, the normal secretion of the gland, and in the lacrimal probe specimens in the separate series of cases, originated not from the ducts but were contaminants lying on the labia minora and derived from the urethra, para-urethral ducts, and endocervix. Confirmation of the hypothesis that such infection does occur must await the examination of a large number of patients. This should yield a number of cases in which gonococci are isolated from Bartholin's ducts and not from any other site.

In this series two such cases were found, and mucopus was expressed in both. Since this paper was first presented three further cases have occurred; in two clear mucus was expressed, but in the third no secretion was expressed on massage, and the specimen was obtained by use of the lacrimal probe. Cultures were positive in all five cases, but smears were negative in the three cases in which specimens were available.

\section{Summary}

(1) The anatomy and histology of Bartholin's glands are described and the relationship to gonococcal infection is discussed.

(2) The results of an examination of the glands in 182 cases of gonorrhoea in women are given.

(3) Gonococci were reported present in specimens of discharge expressed from the ducts in 52 $(28.4$ per cent.) of the cases. In two cases gonococci were found at no other site.

(4) The possibility of infection of the ducts occurring in the absence of visible discharge is discussed and the results are given of culture tests made possible by passing a lacrimal probe into the ducts in 28 cases. The limitations of this test and of the interpretation of positive results from normal secretion of the gland are considered.

I am indebted to Professor D. Taylor Robinson, Dr E. C. Armstrong, and Dr G. C. Turner for the culture and sensitivity tests which were carried out at the Public Health Laboratory, Liverpool. Their results confirm my belief that the most important individual in the diagnosis and treatment of gonorrhoea in women is the bacteriologist.

\section{REFERENCES}

Astruc, J. (1737). "A treatise of the Venereal Disease", trans. W. Barrowby, vol. 2, p. 16. London.

Bloom, W., and Fawcett, D. W. (1962). "A Text book of Histology", 8th ed., pp. 60, 61, 616, 617; Fig. 30-34. Saunders, Philadelphia and London.

Bumm, E. (1884). Arch. Gynaek., 23, 327. (cited by Harkness).

Dunlop, E. M. C. (1963). Brit. F. vener. Dis., 39, 109.

Durel, P. (1950). "La blennorragie", pp. 284, 285. Masson, Paris.

Hamm, A. W., and Leeson, T. S. (1961), "Histology", 4th ed., pp. 226, 227, Fig. 131. Pitman, London; Lippincott, Philadelphia.

Harkness, A. H. (1948). Brit. F. vener. Dis., 24, 137. 
Hutfield, D. C. (1965). Ibid., 41, 137.

Jadassohn, J. (1890). Dtsch. med. Wschr., 16, 542, 569.

Jeffcoate, T. N. A. (1957). "Principles of Gynaecology", 1st ed., p. 22, Fig. 12. Butterworth, London.

Nicol, C. S. (1948). Brit. F. vener. Dis., 24, 26.

Novak, E., and Novak, E. R. (1958). "Gynecologic and Obstetric Pathology", 4th ed., p. 18. Saunders, Philadelphia and London.

Shapiro, L. H., and Lentz, J. W. (1965). F. Albert Einstein med. Center, 13, 6, 8.

\section{La bartholinite blennorragique} RÉsumé

(1) L'anatomie et l'histologie des glandes de Bartholin sont décrites et leur relation à l'infection blennorragique est discutée.
(2) Les résultats de l'examen des glandes chez 182 malades atteints de blennorragie sont donnés.

(3) Il a été rapporté que des gonocoques ont été trouvés dans l'écoulement obtenu des conduits chez 52 malades (28,4 pour cent). Dans 2 cas des gonocoques n'ont pas été trouvés ailleurs que dans les écoulements.

(4) La possibilité d'infection des conduits ayant lieu en l'absence d'un écoulement visible est discutée et les résultats des tests des cultures rendues possible par l'introduction d'une sonde lacrymale dans les conduits chez 28 malades sont donnés. Les restrictions de ce test et celles de l'interprétation des résultats positifs des sécretions normales de la glande sont considerées. 